\title{
Psychological Content of Effective Means of Teaching a Foreign Language in Order to Form the Intercultural Competence of Learners of Different Age Groups
}

\section{Психологічний зміст ефективних засобів навчання іноземної мови з метою формування міжкультур- ної компетентності учнів різних вікових груп}

Nataliia Mykhalchuk

Dr. in Psychology, Professor, Rivne State University of the Humanities, Rivne (Ukraine)

ORCID ID: https://orcid.org/0000-0003-0492-9450

Researcher ID: A-9440-2019

E-mail: natasha1273@ukr.net

\section{Наталія Михальчук}

Доктор психологічних наук, професор, Рівненський державний гуманітарний університет, м. Рівне (Україна)

\section{Iryna Koval}

Ph.D. in Psychology, Assistant Professor, Khmelnytskyi National University, Khmelnytskyi (Ukraine)

ORCID ID: https://orcid.org/0000-0002-2048-0000

Researcher ID: B-2173-2019

E-mail: iryna-koval@i.ua

\section{Ірина Коваль}

Кандидат психологічних наук, доцент, Хмельницький національний університет, м. Хмельницький (Україна)

Address for correspondence, e-mail: kpnu_lab_ps@ukr.net Copyright: (C) Mykhalchuk Nataliia, Koval Iryna

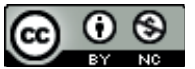

The article is licensed under CC BY-NC 4.0 International (https://creativecommons.org/licenses/by-nc/4.0/)

(C) Mykhalchuk Nataliia, Koval Iryna

DOI (article): https://doi.org/10.32626/2227-6246.2019-46.265-288 
DOI: https://doi.org/10.32626/2227-6246.2019-46

The author's contribution: N. Mykhalchuk $-50 \%$, I. Koval $-50 \%$.

Авторський внесок: Н. Михальчук - 50\%, І. Коваль - 50\%.

\section{ABSTRACT}

In this article there were described local conditions, which included, in particular, the features of a school system, curriculum and programs. We proposed recommendations which were very useful for teachers who made individual plans of their professional activity. There were studied Italian experience of structuring and developing the socio-cultural component of the content of teaching English in order to form the intercultural competence of learners of different age groups.

The authors of the article proposed the most effective learning methods which in a great degree influence on the intercultural competence of learners of different age groups. These methods are: to describe local conditions, which include, in particular, the features of a school system, a curriculum and programs; to propose recommendations which are very useful for teachers who make individual plans of their professional activity; to study Italian experience of structuring and developing the socio-cultural component of the content of teaching English in order to form the intercultural competence of learners of different age groups; to propose the most effective learning methods which in a great degree influence on the intercultural competence of learners of different age groups; to present necessary educational equipment which is the most effective to learn English.

We also presented necessary educational equipment which was the most effective to learn English. Among the main requirements for the structure and the content of the textbook there are such as: the textbook should provide a sequence of the provision of speech and speech material from one lesson to another one; the contents of the textbook should be communicatively oriented; each paragraph of the textbook must have a "rod" around which all material is organized (such "rod», for example, may be a typical phrase, a topic, etc.); in the structure of the parag raph there should be a special section - a homework; the structure and the content of the textbook should provide simultaneous mastery of skills of both oral and written communication.

It was shown that the most motivated phonogram is used: for the purpose of teaching listening; providing oral speech training based on the widespread use of speech samples; rational presentation and fixing of broadcasting samples that are sounding (for example: models, typical structures); introduction of (C) Mykhalchuk Nataliia, Koval Iryna

DOI (article): https://doi.org/10.32626/2227-6246.2019-46.265-288 
speech material in dialogical form; demonstration of songs and fragments of artistic reading in the performance of native speakers; conducting analysis of recorded film statements of pupils; audio-visual aids. Only in such a way it is possible to form the intercultural competence of learners of different age groups.

Key words: intercultural competence, a curriculum, programs, socio-cultural component, communicatively oriented, oral speech training, audio-visual aids.

\section{Introduction}

The profound changes in the socio-political and economic life of European and world countries are increasingly effecting according to the development of their educational systems. The steady tendency of humanization and tolerance of the whole complex of school disciplines should facilitate the pupils' readiness for active life in a changing world, refusal from ideas of ethnocentrism, mastery of modern forms of interpersonal and interethnic relations. World and regional integration has already overcome the block of economic and military-political strategies, led to the formation of a fundamentally new multidimensional socio-cultural space. In this situation, educational systems in many countries aim to prepare pupils for cultural, professional and personal communication with representatives of other countries, to familiarize them with their traditions, social structure and linguistic culture. Thus, in the educational policy of the European Union it was decided to allocate the Basic Complex of Integrative Disciplines, which would include comparative history, the foundations of law and economics, language and literature, sociology and cultural studies. Such a complex, covering humanitarian disciplines and aimed at identifying individuals in national cultures and their connection with universal values, should also give an idea of the «European consciousness», promoted the development of intercultural communication skills.

The school is seen as the instrument of the development of the younger generation in a sense of belonging to European civilization, to modern life which there is Europe as a whole. The

(C) Mykhalchuk Nataliia, Koval Iryna DOI (article): https://doi.org/10.32626/2227-6246.2019-46.265-288 
DOI: https://doi.org/10.32626/2227-6246.2019-46

idea of a European dimension in education was proclaimed in 1989 in the Recommendation of the Parliamentary Assembly of the Council of Europe III (1989) «The European Dimension in Education» (Fernandez, 2016). Specifically, it was emphasized the need for the formation of a genuine European consciousness of citizens and the inclusion of European ideas into the content of the most school disciplines. Let's show in details what exactly means the expression «European dimension in education»:

- the desire to understand the representatives of different countries and cultures, to overcome prejudice towards them, to recognize their common interests, respecting national ones;

- openness to different cultures, protection of cultural identity of each person;

- respect for legal obligations and legal decisions within the framework of human rights;

- the desire to coexist in harmony and to compromise, allowing the reconciliation of interests of different parties;

- the protection of freedom, pluralistic democracy, human rights and affairs;

- the development of the system of production and economic exchanges between the states, which are factors of individual and social well-being of political stability;

- the concern for the preservation of ecological balance in Europe and in the world in a whole;

- the desire to preserve peace in Europe and in a whole in the world.

Since until recently, especially at the secondary school level, education has been depended on the needs and realities of its state. And, in such a way, limitations of this approach have become apparent. The development of the mobility, the presence in a class of a multinational pupils audience, the evolution of the employment market - all these factors are sufficient to prove the inconsistency of the concept of so called «closed school» with modern realities. Therefore, at the Permanent Conference of the Ministers of Education and Culture of the C Mykhalchuk Nataliia, Koval Iryna

DOI (article): https://doi.org/10.32626/2227-6246.2019-46.265-288 
DOI: https://doi.org/10.32626/2227-6246.2019-46

Land of Germany (December 7, 2018), the idea was expressed that today the school's task had been revised the rapprochement of peoples and European states with the aim to reorganize their relations. In order to prepare young people for life in the European continent in a great degree adequately, it is necessary to ensure their knowledge, skills and experience of adaptation to the ever-changing social context, for which purpose pupils have to possess information technologies in order to be able to deal with various sources of various kinds of information and are able to obtain and analyze this information (Галузинський \& Євтух, 1995).

The need to fulfill the content of school education with socio-cultural aspects is recognized today as a priority task both at pan-European and national levels. As the analysis shows, virtually all national programs of European countries in relation to foreign languages contain (de facto) the socio-cultural component of the content of teaching as its component. However, as a rule, this component is presented very limited, without taking into account the requirements of time and new developing trends, because contemporary educational programs always have certain conservatism. This gap is successfully complemented by various projects implemented at the local, school, municipal and international levels. The analysis of available literature on this issue (Mykhalchuk, 2013; Онуфрієва, 2013) made it possible to compare and generalize the experience of leading European countries in structuring the socio-cultural component of the content of teaching a foreign language, to determine the directions of its development and to identify influential factors.

So, the aim of our article is to describe means of teaching a foreign language which are essential for ensuring full and effective organization of educational work of pupils at the lessons with the aim of mastering foreign language activities and with a purpose to develop the intercultural competence of learners of different age groups.

(c) Mykhalchuk Nataliia, Koval Iryna

DOI (article): https://doi.org/10.32626/2227-6246.2019-46.265-288 


\section{The tasks of the research}

1. To describe local conditions, which include, in particular, the features of a school system, curriculum and programs. 2. To propose recommendations which are very useful for teachers who make individual plans of their professional activity.

3. To study Italian experience of structuring and developing the socio-cultural component of the content of teaching English in order to form the intercultural competence of learners of different age groups.

4. To propose the most effective learning methods which in a great degree influence on the intercultural competence of learners of different age groups.

5. To present necessary educational equipment which is the most effective to learn English.

\section{Methods and methodical instrumentation of the research}

The following methods were used in our research: a categorical method, a structural-functional method, the methods of: analysis, systematization, modeling, generalization.

\section{The results of the research and their discussion}

First of all, social and political conditions that are typical for pupils' environments are also very influential, since they determine the choice and interpretation of information and, as a result, determine the relationship between pupil's socio-cultural attitude and the socio-culture of people whose language has being studied. The selection of topics and interpretations of events also depends on the choice of vocabulary both native and foreign. Schools as social institutions that prepare young people for further life in our society serve to familiarize their pupils with the doctrine commonly accepted in this society, such as: "Who we are and how we percept others». To highlight this situation, one can use the peculiarities of structuring socio-cultural component according to the content of teaching (C) Mykhalchuk Nataliia, Koval Iryna

DOI (article): https://doi.org/10.32626/2227-6246.2019-46.265-288 
English and Ukrainian. In the years after the Second World War socio-political conditions of the Federal Republic of Germany allowed the educational institutions of the country to cover the Anglo-American society and the way of its life as a model for the younger generation. Accordingly, the educational program in English as the first foreign language envisaged the assimilation of not only linguistics, but also socio-cultural aspects of people's life in general. Scientists deeply studied the monuments of Anglo-American culture, their influence on the development of German and World culture. Prominent figures and significant events of British and American history were in the focus of contemporary English classes. And after two decades, when West Germany, as a full partner, entered into a military, political and economic alliance with the Western powers, in 1963 significant changes were also made educational program of English as a foreign language: «Studying English and American literature should aim to familiarize with the cultural heritage of other nations, which in turn will contribute to understand the contemporary cultural, political, social and economic life of the population of these countries. Students need to be impartially acquainted with the way of life of other peoples, to respect their successes and to feel shared responsibility both for the past of Western Europe and for resolving issues on both sides of the borders that presents us with our present» (Canale \& Swain, 1980: 12).

The educational goal of studying English within the conditions of general school of the German Democratic Republic (GDR) is quite clearly stated in the 1978 Educational Program. It emphasized that world imperialism is a system hostile to humanity and a labor-wielding working class are an irreconcilable struggle for a happy future. Comparing the way of life of the working class of the GDR with the lives of workers in other countries at the lessons of a foreign language will increase the confidence of students in the benefits of socialism. If in Germany English and French were the languages of «friendly» na-

(C) Mykhalchuk Nataliia, Koval Iryna DOI (article): https://doi.org/10.32626/2227-6246.2019-46.265-288 
DOI: https://doi.org/10.32626/2227-6246.2019-46 2019. Випуск 46 tions, then at the time of the PDR (People Democratic Republic), the people whose native languages were English and French from the ideological point of view belonged to the enemy camp, therefore with relief looked at such characteristic features as uncompromising and impenetrable. As for studying the Russian language at schools of the GDR as a foreign language, the instructions were rather restrained in the assessments and very similar to the West German with their respectable attitude for studying English. One can conclude that a socio-political factor joined with the basic conceptual approach according to youth preparation for life in the society, has a tremendous impact on the process of studying the socio-cultural component of the content of teaching a foreign language (Celce-Murcia \& Hilles, 1988).

Significantly affecting the local conditions, which include, in particular, the features of a school system, curriculum and programs. For example, you can look at Italy, which is characterized by its flexibility. The Ministry of Education at the state level defines the main directions of education, its goals and objectives to be achieved by pupils of different levels of education. Such recommendations are very useful for teachers who make individual plans of their professional activity. In the field of teaching foreign languages recommendations are required to study the «cultural aspects» of a foreign language, but specific instructions from the didactic point of view are not given. Given the timing of the Italian National Program's mismatch, the project organizers have found a way to solve this problem with satellite television. In this way it becomes possible to use a huge amount of information and through awareness of pupils of the peculiarities of native and foreign culture to reduce the level of ethnocentrism, to bring tolerant attitude to representatives of other cultures. This is the goal of the project «Mass Media as a Way to Develop Students' Autonomy» (Mynard \& Ludwig, 2017).

(C) Mykhalchuk Nataliia, Koval Iryna

DOI (article): https://doi.org/10.32626/2227-6246.2019-46.265-288 
It was attended by pupils of 35 classes of different ages, teachers of English, German, French and Spanish, who have received special training in courses on the use of satellite television in the process of teaching a foreign language and presenting culture (for 20-50 hours), providing effective recordings of programs. Realization of the project lasted for a year. At the end the pupils were given the opportunity to listen to the interview, in which they participated during the first year, answering the questions, and the main purpose of which was to study the level of ethnocentrism of each pupil. Almost all the scholars have come to the conclusion that before the project was completed they would have superficial knowledge and a biased attitude to the culture and the country the language of which had being studied.

As the authors of the project emphasize, the cultivation of personalities is capable of respecting representatives of other cultures. It is a very important thing nowadays. Satellite television provides a great access to modern authentic materials, facilitates the activation of the learning process, creates an attractive and flexible learning environment. The pupil feels himself/herself as a researcher and a pioneer. The task of the teacher in this process is the development and widespread use at schools some methods of cultural analysis, strengthening the connections between «experience» and «acquiring knowledge» (Lado, 1990).

The Italian experience of structuring and developing the socio-cultural component of the content, the essence of which is the decoding of multi-story television plots and the training of obtaining additional information of socio-cultural nature from a variety of sources, and in this way to increase significantly the level of background knowledge. It is, in our opinion, extremely useful and worthy to follow. And the local conditions that cover the flexibility of the curriculum, the programs and material opportunities of schools, is one of the factors that influence the structuring of socio-cultural component of the

(C) Mykhalchuk Nataliia, Koval Iryna DOI (article): https://doi.org/10.32626/2227-6246.2019-46.265-288 
content of teaching a foreign language at European secondary schools. Indeed, it is up to pupils to create attractive and flexible environment for learning, using the latest technical advances (satellite TV, Internet, video and audio), access to understand authentic materials. And this, of course, significantly increases the level of motivation of pupils, gives them the opportunity to understand the differences in native and foreign languages, promotes the education of tolerant attitude towards them among representatives of other cultures, reducing the level of ethnocentrism.

Among the historical and cultural factors we consider it expedient to highlight, the first and the foremost, the traditions of learning a foreign language. For example, you can take Britain, where until the 70-es of the XX-th century the main was the structural-grammatical approach, and the ability to read the classics of European culture was aimed at teaching foreign languages. This method of learning was completely in line with the methods of teaching classical languages, especially Latin. Consequently, the school course of teaching a foreign language did not anticipate the development of socio-cultural competence.

Changes that began in the 70's have been continued to this day. Since 1988 a foreign language course has been introduced for obtaining a «General Certificate of Secondary Education». Its main purpose is formulated in such a way: «To develop skills you have to use effectively a foreign language for the process of communication" .

In 1992 a new version of the National Curriculum, the implementation of which is mandatory for public schools, entered into force. According to this document all pupils from the age of 11 must study foreign languages (in Scotland - from 12 years old). Inclusion of a foreign language into the National Curriculum, which is mandatory for all municipal schools in Britain, indicates that the government is aware of the need for the citizens to learn foreign languages for economic prosperity (c) Mykhalchuk Nataliia, Koval Iryna

DOI (article): https://doi.org/10.32626/2227-6246.2019-46.265-288 
and the fact that the country lags behind in this area of education (Oiler, 1992). However, it should be noted that, despite the government's efforts to intensify the teaching of foreign languages at schools, the situation in this area is still unsatisfactory. The British, in comparison with other inhabitants of the Western European countries, speak foreign languages considerably worse. The main reasons for this are:

- late beginning of studying a foreign language (11-12 years old);

- wrong choice of languages - French as the first foreign language (there is the opinion that it is easier for a person with native English to study German than French);

- not enough time is spent on studying a foreign language (on average 2 hours per week for five years);

- insufficient number of foreign language teachers;

- low quality of textbooks, despite their wide choice.

It should be noted that the UK's national specificity in foreign-language education is a low level of reasoning for teaching a foreign language by pupils of both British and non-British descent. According to the British themselves, for a long time the word «language» ( «мова») was synonymous for them as «English» ( «англійська лова»). And today British residents do not worry that they will have difficulties in communication, falling into any part of the world, since English is so widespread that perhaps it is possible to be more surprised at its ignorance than from ignorance of a native language.

British educators regard as a serious problem the fact that pupils studying this or that foreign language at school may find themselves in a situation where they will need knowledge of a completely different language. Therefore, in the UK the school stage of education is understood as preparing for a more serious study of a foreign language in the future. The program of studying a foreign language in the UK is aimed at preparing pupils for independent reading of literary courses and preparation for study abroad. Skills and abilities in a case of a foreign

(C) Mykhalchuk Nataliia, Koval Iryna DOI (article): https://doi.org/10.32626/2227-6246.2019-46.265-288 
language should help to clarify a large number of issues related to the national, political, social, economic, cultural life of the country having been studied, as well as in the comparison and the analysis of phenomena, events, processes of the national language life and life abroad (Underbill, 1989).

In addition, one more reason is worth mentioning of one consistent trend: to study the cultural features of the people of the language having been studied and a foreign language read only in literature, which is clearly not enough for a resident of a modern European country. In order to improve the level of foreign-language socio-cultural competence of pupils from Great Britain and France in the period from 1990 to 1993, a joint British-French project was organized in which both foreign language specialists and practicing teachers took part. Let's show how this project was carried out by the British side under the leadership of Michel Biram. The basis of the already existing sociology course was used. The purposes of the British side were:

- to provide pupils with information about the socio-cultural plan, which sometimes remains beyond their control;

- practically prove that cultural phenomena which is the most clearly manifested in a certain economic or political perspective;

- to teach to work with a limited amount of information;

- to teach to avoid negation and rejection of any phenomena of a foreign-language culture.

Particular attention was paid to prevent the emergence of new stereotypes that could replace the old ones. The activity has the aim to study five main topics:

1. Family and family holidays in France and the UK; family structure, relatives; rituals associated with eating.

2. Education in France and the UK.

3 . The work and the process of socialization in the countries of Europe, prestigious professions, rest.

4. National identity and multi-ethnicity in France and Great Britain.

(C) Mykhalchuk Nataliia, Koval Iryna

DOI (article): https://doi.org/10.32626/2227-6246.2019-46.265-288 
5 . The development of empathy with the French population and an attempt to feel like a Frenchman through the widest use of ethnographic technologies for teaching a foreign language.

As the organizers and participants of this project, as a result of its implementation we have to say that the level of all components of the foreign-language communicative competence of pupils has increased significantly, while in evaluating the determinants have become openness and tolerance, readiness to perceive the phenomena of a foreign language culture and revise its own ethnocentric position. It can be concluded that, despite the lack of perfection of the system of teaching foreign languages at secondary schools of Great Britain compared with other European countries, the British experience in developing the socio-cultural component of the content of the curriculum is interesting, useful and worthy to follow.

Means of education are the important component of the foreign language learning process at secondary schools. Definition of teaching aids is the answer to the question «What to teach?» Thus, learning materials can be various structural objects that help the teacher to organize effective learning of a foreign language, and pupils have to master it successfully.

In the methodology of teaching foreign languages the means of training were put forward certain requirements. So, learning methods should:

a) to act in a form of material and perform its main functions, to be the means of the activity that ensure the activity of the teacher and the activities of pupils in the educational process of studying a foreign language;

b) to be oriented towards the purpose of training, that is to contribute to the achievement of goals in the process of teaching a foreign language;

c) to be instruments of the implementation of methods and techniques used in the educational process, and ensure the management of the activities of the teacher and the activities of pupils;

(C) Mykhalchuk Nataliia, Koval Iryna DOI (article): https://doi.org/10.32626/2227-6246.2019-46.265-288 
d) to correspond to the modern achievements of the methodology of teaching foreign languages and ensure the implementation of the latest technologies of teaching a foreign language.

According to such criteria as significance, the purpose and the application of technical equipment means of teaching a foreign language are divided into: a) basic and auxiliary; b) directed on a teacher and pupils; c) technical and non-technical.

Ideally, all these means should be presented in the educational-methodical complex, which teaches use at the classes of a foreign language in this or that period at secondary school. In this case the educational and methodical complex is the main means of learning in its entirety of its components: a textbook, books for a teacher, a lingua-phone workshop, computer programs, a set of slides, tapes, audio and video cassettes, tables, etc. All those components mean that the teacher uses basic teaching aids in addition and he/she considers them as auxiliary ones. In such a way series of drawings, teacher-distributive training cards, tables, diagrams, as well as illustrated magazines, posters, photographs, etc. have to be selected specially.

\section{Conclusions}

When choosing the means of teaching a foreign language, first of all a textbook, it is necessary to remember their correspondence with the age-specific features of pupils, the level of their language and language training, the realities of modern life, and the requirements of the current program.

All these mean that the process of teaching a foreign language is intended as for the teacher so for a pupil. The kit for a teacher consists of the State Standard and the Foreign Language Program, a teacher's book, a manual for extracurricular activities, a set of phonograms and video phonograms, tables, drawings, a collection of exercises, a magnetic board, a set of slides and films.

The teacher's book is an important component of the teacher's complex. It describes the principles and the main metho(c) Mykhalchuk Nataliia, Koval Iryna

DOI (article): https://doi.org/10.32626/2227-6246.2019-46.265-288 
dological idea of the educational complex, provides methodological guidelines for working with the textbook and methodical instructions for each lesson, offers exercises for teaching listening, speaking, etc., which are complement for the textbook material. Teacher's book as a learning tool is designed for teachers, allows them to organize pupils' learning activities more effectively and use all components of the educationalmethodical complex.

The means for each pupil include a textbook, a book for reading, directories, dictionaries, handout materials, exercises on a printed or audio cassette, videograms (slides), computer programs.

As a learning tool the textbook occupies a special place in a pupil's kit, which is the main textbook. It contains methodically organized speech, speech material, exercises for mastering this material in various types of speech activity (exception is the texts for listening from the book for a teacher), grammar reference material, appendix (songs, poems, vocabulary, etc.).

The structure of the textbook to a certain extent depends on the methodological concept of the authors. Traditionally, textbooks are organized in a thematic or situational-thematic principle in sections that are relatively complete sections according to the content of teaching including four types of speech activity: speaking, listening, reading and writing. Each section usually covers a series of lessons and has a pyramid structure. Various visualizations can be used in the textbook: charts, tables, drawings, symbols, different fonts, colors, etc. So, the textbook should contain everything that is necessary for the purpose of learning. Among the main requirements for the structure and the content of the textbook there are such as:

1) the textbook should provide a sequence of the provision of speech and speech material from one lesson to another one;

2) the contents of the textbook should be communicatively oriented;

(C) Mykhalchuk Nataliia, Koval Iryna DOI (article): https://doi.org/10.32626/2227-6246.2019-46.265-288 
3) each paragraph of the textbook must have a «rod» around which all material is organized (such «rod», for example, may be a typical phrase, a topic, etc.);

4) in the structure of the paragraph there should be a special section - a homework;

5) the structure and the content of the textbook should provide simultaneous mastery of skills of both oral and written communication.

The means of teaching a foreign language can be used with or without the use of the appropriate technical equipment. Those means require the use of technical equipment, they are called technical means of training. Other means are nontechnical. Among the technical means of training, the methods of which are carefully developed, scientists distinguish videograms, phonograms and video phonograms.

It should be noted that even with a minimum of educational equipment with technical equipment it is impossible to teach a foreign language without the use of certain technical means of training. From such mean on the first place there is a phonogram. The phonogram is a tool that directs learning language information from the auditory channel of the pupil's sensor system. The phonogram has many advantages over other learning tools because it allows you to:

a) record a foreign language pronunciation in time and space for further use in the educational process;

b) to demonstrate the object of mastering - the foreign language pronunciation sound;

c) to make "preserved speech» in accordance with any other methodological plan;

d) to control effectively the oral language product of a pupil, giving him / her not only qualitative but also a quantitative assessment.

The most motivated phonogram is used: for the purpose of teaching listening; providing oral speech training based on the widespread use of speech samples; rational presentation and (c) Mykhalchuk Nataliia, Koval Iryna

DOI (article): https://doi.org/10.32626/2227-6246.2019-46.265-288 
fixing of broadcasting samples that are sounding (for example: models, typical structures); introduction of speech material in dialogical form; demonstration of songs and fragments of artistic reading in the performance of native speakers; conducting analysis of recorded film statements of pupils; audio visual aids.

Recently, the most important is the technique of using computer programs, which is becoming increasingly used today; it is very actively being developed. Computer programs implemented with the help of state-of-the-art computer models in the Multimedia system offer great opportunities for improving the learning process of a foreign language, increasing its efficiency. This is due to the presence in the computer programs of new didactic functions that can not be reproduced, for example, in a video-graph. Besides that the computer program provides perception of information through auditory and visual channels; it also allows to study and to control the process of learning a foreign language in different modes of independent search and at various levels of difficulty.

The use of any means of training must be consistent with the whole system of teaching a foreign language; they have to be in one line with its principles and objectives. This means that the pupils' actions, for example, when working with computer programs, must be motivated, exercises must be responsible for the attitude and situational character of the actual communication process.

So, psychological specificity of socio-cultural information in order to form of intercultural competence of adolescents requires the use by the teacher the following linguistic-national commentaries:

- meaningful comments of the background vocabulary, national realities;

- historical commentary, especially characteristics of working with small forms of childish English folklore;

- visual-behavioural comments, the purpose of which is to give an idea of communicative actions in the most typical situ-

(C) Mykhalchuk Nataliia, Koval Iryna DOI (article): https://doi.org/10.32626/2227-6246.2019-46.265-288 
ations of communication with native speakers: during acquaintance, during a telephone conversation, at school (during a recall, a teacher's greetings, address to him / her, etc.), during compilation letter carriers, etc.;

- combined comments, which include different variations of the above actions.

The content of intercultural competence is also skills and abilities of speech and infanticide behaviour in situations that simulate the dialogue of cultures. These are:

- skills and abilities to operate selected for the initial degree by a minimum of linguistic language material: background vocabulary, national realities;

- skills and abilities of adequate operation of the selected minimum of etiquette and visual units;

- skills and abilities to operate on the selected minimum communicational stereotyped and nationally determined words and expressions used by young English speakers;

- skills and abilities to operate with selected regional knowledge, including knowledge of the rules of everyday behaviour, as well as knowledge of the aesthetic plan: small forms of children's English folklore, accessible examples of fiction, children's animation;

- skills and abilities of creative use of the learned sociocultural knowledge during: 1) independent performance of project tasks; 2) cultural activities within the topics being studied: children's literary and ethnographic studies, competitions, parental meetings in the form of children's report «What we can do at the English lessons», preparation of exhibitions of child's labour works with the corresponding English language presentation, etc.

In our research we have attempted to form intercultural competence on socio-cultural material, that is the formation of grammatical competence which takes place in a logical combination with socio-cultural component. We outlined the stages of formation of socio-cultural skills and abilities, noting, (C) Mykhalchuk Nataliia, Koval Iryna

DOI (article): https://doi.org/10.32626/2227-6246.2019-46.265-288 
first of all, that separating these stages of teaching English from the stages of formation of grammatical skills can only be conditional. Also we distinguished two main stages: the first stage is a stage of acquisition of socio-cultural knowledge and situational training; the second stage is a stage of situational use of socio-cultural knowledge.

At the first stage pupils receive socio-cultural information and workouts to use socio-cultural knowledge.

At the second stage pupils independently use their acquired socio-cultural knowledge when creating their own dialogues and monologues, in a group conversation.

Therefore, means of teaching a foreign language are essential for ensuring full and effective organization of educational work of pupils at the lessons with the aim of mastering foreign language activities and with a purpose to develop the intercultural competence of learners of different age groups.

\section{Literature}

Галузинський В. М., Свтух М. Б. Педагогіка: теорія та історія. Київ : Вища школа, 1995. 237 с.

Онуфрієва Л. А. Дослідження психологічних детермінант розвитку професійної самосвідомості та особистісної зрілості майбутніх фахівців соціономічних професій. Науковий вісник Миколаӥвського державного університету ілені В. О. Сухоллинського: зб. наук. праць. Серія "Психологічні науки» / за ред. С. Д. Максиленка, Н. О. Свдокилової. Миколаїв : МНУ імені В. О. Сухомлинського, 2013. Т. 2. Вип. 10 (91). С. 227-233.

Canale, M., \& Swain, M. (1980). Theoretical Bases of Communication Approaches to a Second Language Teaching and Testing. Applied Linguistics, 1, 1-47.

Celce-Murcia, M., \& Hilles, Sh. (1988). Techniques and Resources in Teaching Grammar. Oxford : Oxford Univ. Press. 189 p.

Fernandez, A. D. (2016). The European Dimension in Education. URL : https://www.google.com.

Lado, R. (1990). Linguistics Across Cultures: Applied Linguistics for Language Teachers. Michigan. $141 \mathrm{p}$.

Mykhalchuk, N. O. (2013). Intercultural communication and culturallyoriented teaching of students a foreign language in high school. Oco-

(C) Mykhalchuk Nataliia, Koval Iryna

DOI (article): https://doi.org/10.32626/2227-6246.2019-46.265-288 
DOI: https://doi.org/10.32626/2227-6246.2019-46 2019. Випуск 46

бистість в екстрелальних уловах. Матеріали 6 Всеукр. наук.практ. конф. з міжнародною участю (7-8 листопада 2013 р.). Львів. Ч. 1. С. 41-44.

Mynard, J., \& Ludwig, C. (2017). Autonomy in language learning: tools, tasks and environments. URL : https://www.google.com/url.

Oiler, J. W. (1992). Language Tests at School: A Pragmatic Approach. New York : Longman. $492 \mathrm{p}$.

Underbill, N. (1989). Testing Spoken Language: a Handbook of Oral Testing Techniques. Cambridge : Cambridge University Press. 117 p.

\section{References}

Haluzynskyi, V. M., \& Yevtukh, M. B. (1995). Pedahohika: teoriia ta istoriia [Pedagogy: Theory and History]. Kyiv : Vyshcha shkola [in Ukrainian].

Onufriieva, L. A. (2013). Doslidzhennia psykholohichnykh determinant rozvytku profesiinoi samosvidomosti ta osobystisnoi zrilosti maibutnikh fakhivtsiv sotsionomichnykh profesii [The research of psychological determinants of the development of professional self-awareness and personal maturity of future specialists of socio-economic professions]. S. D. Maksymenko, N. O. Yevdokymova (Eds.). Naukovyi visnyk Mykolaivskoho derzhavnoho universytetu imeni V. O. Sukhomlynskoho - Scientific Bulletin of Mykolayiv State University named after V. A. Sukhomlynskyi: Collection of research papers. Series «Psychological Sciences», 2, 10 (91), 227-233. Mykolaiv : MNU imeni V. O. Sukhomlynskoho [in Ukrainian].

Canale, M., \& Swain, M. (1980). Theoretical Bases of Communication Approaches to a Second Language Teaching and Testing. Applied Linguistics, $1,1-47$.

Celce-Murcia, M., \& Hilles, Sh. (1988). Techniques and Resources in Teaching Grammar. Oxford : Oxford Univ. Press.

Fernandez, A. D. (2016). The European Dimension in Education. Retrieved from https://www.google.com.

Lado, R. (1990). Linguistics Across Cultures: Applied Linguistics for Language Teachers. Michigan.

Mykhalchuk, N. O. (2013). Intercultural communication and culturallyoriented teaching of students a foreign language in high school. The person in extreme conditions. Proceedings of the $6^{\text {th }}$ Ukrainian scientific and practical conference with international participation, 1, 41-44. Lviv.

Mynard, J., \& Ludwig, C. (2017). Autonomy in language learning: tools, tasks and environments. Retrieved from https://www.google.com/url.

(C) Mykhalchuk Nataliia, Koval Iryna

DOI (article): https://doi.org/10.32626/2227-6246.2019-46.265-288 http://journals.uran.ua/index.php/2227-6246 
DOI: https://doi.org/10.32626/2227-6246.2019-46 2019. Випуск 46

Oiler, J. W. (1992). Language Tests at School: A Pragmatic Approach. New York : Longman.

Underbill, N. (1989). Testing Spoken Language: a Handbook of Oral Testing Techniques. Cambridge : Cambridge University Press.

Михальчук Наталія, Коваль Ірина. Психологічний зміст ефективних засобів навчання іноземної мови з метою формування міжкультурної компетентності учнів різних вікових груп

\section{АНОТАЦІЯ}

У статті описано психологічні умови, що стосуються особливостей шкільної освіти, навчальних програм і планів, які мають бути спрямовані на формування міжкультурної компетентності учнів різних вікових груп. Запропоновано психологічні рекомендації, які, на думку авторів публікації, $\epsilon$ досить корисними для вчителів з огляду на складання ними індивідуальних планів своєї професійної діяльності. Вивчено європейський досвід структурування та розвитку соціокультурної складової змісту викладання англійської мови з метою формування міжкультурної компетентності учнів різних вікових груп.

Авторами статmі запропоновано найефективніші методи навчання, що значною мірою впливають на становлення міжкультурної компетентності учнів різних вікових груп. Цими методами є: опис психологічних умов навчання учнів, особливості шкільної системи, зміст навчальних програм і планів; запропоновано корисні для вчителів рекомендації з метою актуалізації міжкультурної компетентності учнів різних вікових груп; вивчено психологічні особливості структурування навчального матеріалу з метою наголошення на соціокультурному змісті викладання англійської мови, що, в свою чергу, фасилітує становлення міжкультурної компетентності учнів різних вікових груп; запропоновано ефективні методи навчання, які значною мірою впливають на формування міжкультурної компетентності учнів різних вікових груп.

У статmі представлено необхідне навчальне обладнання, яке є найбільшою мірою ефективним для вивчення школярами англійської мови. Зазначено, що серед основних вимог щодо структури та змісту підручника є такі: підручник має передбачати послідовність презентації навчального матеріалу від одного уроку до іншого; зміст підручника має бути комунікативно зорієнтованим; кожен параграф підручника повинен

(C) Mykhalchuk Nataliia, Koval Iryna DOI (article): https://doi.org/10.32626/2227-6246.2019-46.265-288 
мати чітко структурований зміст, навколо якого організований увесь матеріал (ідеться, зокрема, про типові фрази, теми тощо); у структурі підручника має бути закладено домашнє завдання; структура та зміст підручника повинні забезпечувати одночасне оволодіння навичками як усного, так і писемного мовлення.

Було показано, що найбільшою мірою мотивована фонограма використовується з метою навчання аудіювання; фонограма повинна враховувати: забезпечення комунікативно зорієнтованого навчання на основі широкого використання мовленнєвих зразків (або паттернів) раціонального представлення та фіксації мовленнєвих зразків (наприклад, розмовних моделей, типових структур); уведення мовленнєвого матеріалу в діалогічні висловлювання; демонстрацію пісень і фрагментів художнього читання у виконанні носіїв мови; проведення аналізу записаних учнями кіноповістей; зміст аудіовізуальних посібників. Лише за таких умов можна сформувати міжкультурну компетентність учнів різних вікових груп.

Ключові слова: міжкультурна компетентність, навчальний план, програма, соціокультурна складова, комунікативно зорієнтована складова, мовленнєва підготовка до усного спілкування, аудіовізуальні посібники.

Михальчук Наталия, Коваль Ирина. Психологическое содержание эффективных средств обучения иностранному языку с целью формирования межкультурной компетентности учащихся разных возрастных групп

\section{АННОТАЦИЯ}

В статье описаны психологические условия, касающиеся особенностей школьного образования, учебных программ и планов, которые должны быть направлены на формирование межкультурной компетентности учащихся разных возрастных групп. Предложены психологические рекомендации, которые, по мнению авторов публикации, являются весьма полезными для учителей с учетом составления ими индивидуальных планов своей профессиональной деятельности. Был изучен европейский опыт структурирования и развития сочиокультурной составляющей содержания преподавания английского языка с целью формирования межкультурной компетентности учащихся разных возрастных групп.

(c) Mykhalchuk Nataliia, Koval Iryna

DOI (article): https://doi.org/10.32626/2227-6246.2019-46.265-288 http://journals.uran.ua/index.php/2227-6246 
DOI: https://doi.org/10.32626/2227-6246.2019-46 2019. Випуск 46

Авторами статьи предложены наиболее эфрфективные методы обучения, в значительной степени влияющие на становление межкультурной компетентности учащихся разных возрастных групп. Этими методами являются: описание психологических условий обучения учащихся, особенности школьной системы, содержание учебных программ и планов; предложены полезные для учителей рекомендации с целью актуализации межкультурной компетентности учащихся разных возрастных групп; изучены психологические особенности структурирования учебного материала с челью подчеркивания социокультурного смысла преподавания английского языка, что, в свою очередь, фасилитирует становление межкультурной компетентности учащихся разных возрастных групп; предложены эффрективные методы обучения, во многом влияющие на формирование межкультурной компетентности учащихся разных возрастных групп.

В статье описано необходимое учебное оборудование, которое является в наибольшей степени эффрективным для изучения школьниками английского языка. Отмечено, что среди основных требований к структуре и содержанию учебника являются: учебник должен предусматривать последовательность презентации учебного материала от одного урока к другому; содержание учебника должно быть коммуникативно ориентированным; каждый параграф учебника должен иметь четко структурированное содержание, вокруг которого организован весь материал (речь идет, в частности, о типичных фразах, темах и т. д.); в структуре учебника должно быть заложено домашнее задание; структура и содержание учебника должны обеспечивать одновременное овладение навыками как устной, так и письменной речи.

Было показано, что в наибольшей степени мотивированная фонограмма используется в иелях обучения аудированию; фонограмма должна учитывать: обеспечение коммуникативно ориентированного обучения на основе широкого использования речевых образцов (или паттернов) рационального представления и фиксации речевых образцов (например, разговорных моделей, типовых структур); введение речевого материала в диалогические высказывания; демонстрацию песен и фрагментов художественного чтения в исполнении носителей языка; проведение анализа записанных учениками киноповестей; содержание аудиовизуальных пособий. Только с учетом таких условий можно сфор-

(C) Mykhalchuk Nataliia, Koval Iryna DOI (article): https://doi.org/10.32626/2227-6246.2019-46.265-288 
ISSN 2227-6246 (Print)

DOI: https://doi.org/10.32626/2227-6246.2019-46 2019. Випуск 46

мировать межкультурную компетентность учащихся разных возрастных групп.

Ключевые слова: межкультурная компетентность, учебный план, программа, социокультурная составляющая, коммуникативно ориентированная составляющая, речевая подготовка к устному общению, аудиовизуальные пособия.

Original manuscript received September 17, 2019 Revised manuscript accepted October 09, 2019

(C) Mykhalchuk Nataliia, Koval Iryna

DOI (article): https://doi.org/10.32626/2227-6246.2019-46.265-288 http://journals.uran.ua/index.php/2227-6246 